\title{
Recasting Anthropological Perspectives on Vernacular Islam in Southeast Europe An Introduction
}

\author{
DAVID HENIG and KAROLINA BIELENIN-LENCZOWSKA
}

When Tone Bringa published Being Muslim the Bosnian Way in 1995, the book soon became the hallmark of anthropological studies of Islam in Southeast Europe. In the wake of the tragic events in BosniaHerzegovina ensuing from the breakdown of Yugoslavia, it provided much needed intimate insights into the complex entanglement of religion, politico-religious symbolism and identitarian politics in the wartorn country. Furthermore, it complicated the immediate proliferation of the 'quick solution' paradigms - clash of civilisations, or 'old' ethnic hatred - that had been adopted with ease by many international and local politicians, as well as by scholars working in the region, and that soon became the mainstream of academic discourse during and especially in the years after the war. There is, however, another line of argument in the book that has remained, in our view, unexplored in the scholarship of Islam in former Yugoslavia, and in Muslim Southeast Europe more generally. In Being Muslim the Bosnian Way, Bringa sketched out in great detail the ways Bosnian Muslims articulate and negotiate moral dilemmas, and the very notions of living a Muslim life in the fin de l'époque of socialist Yugoslavia, and how these were radically shattered by the conflict-driven socio-economic changes as much as by considerable metamorphoses in religious landscape that had predated the socialist disintegration in the region (cf. also Sorabji 1989; Duijzings 2000). At the end of her lucid ethnography, Bringa raised a point that is worth repeating here:

The war changes people and it changes their perceptions of who they are. As a reaction to and part of the process of the war and the politics behind it, many Bosnian Muslims are redefining both the content and function of their collective identities, and identifying with a wider world community of Muslims more than before. To what extent these changes signal a more assertive Islamic identity and an extension of a Muslimdefined identity by expanding the use of Islamic discourse and symbols into new domains (e.g., specific Muslim greetings), or a redefinition of Muslim identity, is a subject for further research. (1995: 197-198) 
As Henig (2012: 762) recently pointed out, two decades after the breakdown of the former Yugoslavia and more than fifteen years since Bringa discussed the future direction of anthropological research on vernacular Islam in Bosnia-Herzegovina - the top-down driven hegemonic interpretation of Bosnian Muslim politics as trapped in the politics of identity and inter-communal ethnoreligious nationalism - prevails in the media, political debates, and the international community's projects as well as in academic discourses. The point raised by Tone Bringa can arguably be extended into the wider context of post-socialist Muslim lives in the region: how has the disintegration of state socialism in Southeast European countries affected the state administration and bureaucracy of religious life, and more importantly the spheres of moral imagination, belonging and vernacular cosmologies among numerous Muslim communities? Now imagine if Tone Bringa's double had raised a similar point about the future directions of anthropological research on vernacular Islam in, say, Albania, Bulgaria, Kosovo or Macedonia. The characteristics of the situation would be perhaps similar to those outlined by Henig in the Bosnian context, as if ethnoreligious nationalism and identitarian politics were the only interpretative possibilities for the human condition in the region.

This somewhat unsatisfactory development of the anthropological agenda on living Islam and Muslim communities in Southeast Europe was the major impulse for bringing together a new generation of anthropologists from across Europe, and from divergent disciplinary traditions working in the region to explore the state of research on the issues of vernacular Islam in the Balkans. We wanted to know what the commonalities or differences in predicaments, challenges as well as hopes are which Muslim communities, and Muslims of different walks of life in Southeast Europe face nowadays, and how this is (un)reflected in the scholarship. Taken together, the essays collected in this issue give a glimpse of the aforementioned 'what if' thought experiment to discuss in fine ethnographic detail various aspects of the politics, identity and moral creativity of Muslim lives in contemporary Southeast Europe, more than two decades after the disintegration of socialist states, and vis-à-vis new geopolitical challenges. What all the case studies gathered in this issue thus have in common is a shared legacy of the Ottoman empire, and more recently of the socialist period in which the state appropriated and controlled to a greater or lesser extent all spheres of life, including public religions as well as the intimate spheres of personal piety (cf. Hann 2006). 
The paths of change in the Muslim religious landscape of Southeast Europe have been multiple in the past two decades and that is also reflected in the diversity of themes and places discussed throughout the following pages. The articles presented in this issue will transport the reader to Albanian villages to explore how the poetics of friendship can be a more persuasive trope of sociality than the Orthodox-Muslim divide, fostered in hegemonic public discourses, as Eckehard Pistrick shows us. In the streets of Sarajevo, as Andreja Mesarič persuasively illustrates, veiling is not necessarily a performance of ethnonational identity vis-à-vis other religious traditions, but can also be an expression of individual piety and the moral aesthetic of being a good Muslim. Marta Kołczyńska explores how a newly built asphalt road connecting a Muslim pilgrimage site in the Albanian highlands became a symbol of religious revitalisation as much as of post-socialist moral decline. Anna Zadrożna provides a bottom-up perspective on the ways Muslims in the Republic of Macedonia narrate, negotiate and imagine their religious identities, and what the perils of belonging are for Macedonian Muslims situated at the margins of Europe as well as Islamic umma. Finally, Magdalena Lubanska's ethnographically grounded essay challenges the arguments about religious syncretism and competitive sharing of sacred sites in a multi-religious context by examining the Muslim motivations for attending Christian holy places in the Rhodopes, Bulgaria. Overall, the essays in this issue reanimate the analytical perspective towards the direction that we recognise as vernacular Islam.

\section{Towards Vernacular Islam}

The reason why we took Tone Bringa's book as a point of departure for our Introduction is both inspirational and instructive. In our view, the book was pioneering in its detailed anthropological analysis of vernacular Islam in the region of Southeast Europe. And it is instructive from a scholarly perspective as it forged a space for recognising the significance of vernacular Islamic cosmologies, religious practice, and moral reasoning and imagination in the lifeworlds of Muslims in the region, rather than interpreting the material solely as a matter of political identity or ethnoreligious hatred. We acknowledge that the latter are important for understanding the processes in the region as well, but we feel uneasy about their continuous predominance in the analytical prism and debates, thus marginalising other themes 
and predicaments that Southeast European Muslim communities are facing nowadays.

Gerald Creed (2011) recently pointed out, based on his research of ritual revitalisation in post-socialist Bulgaria, that the scholarly insistence and privileging of ethnonational identities and their interactions has overlooked the importance of place identities, and the role of rituals, and localised forms of knowledge and practice. As Creed observes, the exclusion of the latter 'in analyses of this part of the world is an example of Balkanism par excellence' (2011: 168). For Creed, it is ritual that works as a way to de-authorise the former hegemonic analytical perspectives. In a similar vein, Joao de Pina-Cabral and Frances Pine (2008) invigorated the concept of margin and marginality in relation to religion and religious life for our contemporary moment. The perspectival shift Pina-Cabral and Pine propose moves the analytical focus from centres of power, religion and politics to the seemingly marginal spheres where rhetoric, ideology and discourse are 'written on the body, inscribed on built space and landscapes, or where it is present in a silenced or silent mode' (2008: 4).

In this issue, we take both arguments as a source of inspiration and we want to explore the forms of vernacular Islam as a way to give nuance to and/or de-authorise the dominant scholarly perspective, and hegemonic (inter)national political discourses, on Muslim lives in the region and their entanglements with turbulent changes of recent decades as well as in the present. Therefore, when we are referring to vernacular Islam in post-socialist Southeast Europe, we want to embrace and highlight the interplay between vibrant knowledge traditions, quotidian experiences and social aesthetic forms with the divine cosmologies and practices, contextualised within historical vicissitudes and shifting political geographies.

The forms and expressions of vernacular Islam in contemporary Southeast Europe are multifaceted, and, to paraphrase Pina-Cabral and Pine, 'written on the body, inscribed on built space and landscapes'. Indeed, let us recapitulate a few highlights from a quick Internet search as well as from our own fieldwork encounters to illustrate this argument at grass-roots level. One, often dominating image in Western media is that of 'Wahabisation' of Southeast Europe. It is true that there has been not insignificant, though haphazard proliferation of Salafi (or Wahabi) movements in the region. The attacks on the Harabati Baba Tekke (a dervish lodge of the Bektashi order) in Macedonian Tetovo, or on the participants of the Queer festival in Bosnian Sarajevo have been reported widely. However, as we illustrate in this issue, these Salafi 
groups are for the great majority of local Muslims a source of discontent and in the vernacular conversations also a source of irony, jokes and mockery rather than a sign of radicalisation (see Zadrożna, this issue). On the other hand, the recently organised 'Halal conference' that brought together Islamic financial institutions and businesses from all around the Muslim world to Sarajevo, illustrates shifting economic geographies of Islam, and an increasing significance of Southeast Europe for the Muslim business world, and for the Republic of Turkey in particular. Indeed, Turkish folkloric groups performing sema (a 'whirling' dervish dance), can often be seen at various parades and feasts throughout the region, and Turkish has been added to the curriculum in some areas as an optional foreign language. Many international Islamic humanitarian organisations have left their imprints in the landscapes, as is indicated by the mushrooming of new mosques almost everywhere (e.g. Ghodsee 2010). The increasing popularity of Islamic Internet forums among Muslim youths (see Mesarič, Zadrożna, this issue), frequent book festivals with expanding Muslim spiritual book production, well-liked Islamic religious radio and television stations, or special broadcasting programmes during the holy month of Ramadan, and the omnipresence of advertising magazines in which Quranic healers offer protection against loans, debts and unemployment, are other facets of vernacular Islam and moral creativity in the public spheres in the region (for ethnographic examples see Edgar and Henig 2010: 255-260; Jasarević 2012).

This brief illustration of what we understand by 'vernacular Islamic perspective' in Southeast Europe unfolds as an assemblage of Muslims' actions, experiences and practices along with the processes of post-socialist liberation of religious conduct in the context of shifting symbolic geographies, and the new place of the region on the map of the Islamic world, as well as on the roadmap to EU accession, or as in the Bulgarian case, literally on the map of the European Union (Lubanska, this issue). The intersection of quotidian practices, symbolic geographic imaginations with moral geographies of Islam significantly shapes the negotiations and questioning of what it means to be a Muslim in Europe, or what it means to live a good Muslim life on the margins of the Muslim world. These events and processes, and local conversations about them, have been somewhat marginalised in the dominant scholarship on changing faces and trajectories of religious life in post-socialist Southeast Europe, and this issue aims to bring these questions from the margins into the central focus of anthropological attention. 


\title{
Recasting Attention, or Where to Go?
}

The historical vicissitudes, geopolitical criss-crosses, reanimation of symbolic geographies and identitarian dilemmas of belonging in Muslim Southeast Europe, however, open up another question in relation to the scholarship we want to address in this issue. Let us return to Tone Bringa's book once again, specifically to the first lines of the introduction, where we read:

\begin{abstract}
When I returned from Bosnia-Hercegovina after my first field trip in 1988, I was asked by colleagues in Britain, 'Where is Bosnia?' Today very few Europeans would have to ask that question. For more than three years [...] Bosnia has been making front-page headlines in European newspapers. Even names of villages and small market towns have entered the daily newspaper vocabulary. The first war on European soil in almost fifty years has produced an enormous interest in the region both on the part of the media and that of the academy. Many researchers, historians, social scientists, and others have turned their interests toward the former Yugoslavia. (1995: 3)
\end{abstract}

This observation, although made for Bringa's Bosnian experience, is subtle as it marks the shift in the scholarship on Southeast European Islam from geographies of academic ignorance towards the region as an object of knowledge (cf. Schendel 2002). The shift on the scale of attention is a classic example of what Arjun Appadurai (1986) described as the problem of centres and peripheries in anthropological theory. In his essay, Appadurai provides anthropologists with a useful self-reflexive toolbox while pinpointing the significant interplay between hierarchisation of certain places and hegemony of analytical gatekeeping concepts associated with such places, as an inseparable couple in the making of anthropological theory. In other words, certain themes and places have become canonised and favoured on the scale of attention as the appropriate object of anthropological knowledge and analysis, while others have not, and we should question why and how such marginalisation is fabricated and maintained. Bringa's aforementioned reflection on how Bosnia became part of the knowledge economy literally overnight, as much as other places in the region after the end of the Cold War, points yet again to the arbitrariness of anthropological scales of spatio-conceptual attention and knowledge production (cf. Green 2005, on a similar argument). These are emergent products of specific historical and political vicissitudes that turn regions and themes into objects of anthropological knowledge (cf. Fabian 1983; Buchowski 2006). 
Let us partake in this argument for a moment, and focus only on the region of Southeast Europe. Although a limited number of anthropologists from the anthropological centres were allowed to work in the region in the late 1970s and 1980s (for an overview cf. Halpern and Kideckel 1983) these studies did not explore, largely for the sensitiveness of the topic, the domain of religious practice and vernacular cosmologies (some exceptions are Tone Bringa, Ger Duijzings and Cornellia Sorabji). It is then hardly surprising to read in Bringa's Bosnian ethnography (1995: xv) how in the 1980s she avoided mentioning ethnicity or Islam in her research proposal to gain permits for her fieldwork (also cf. Bougarel et al. 2007: 15). These research constraints were shared by many researchers from the 'centres' working in Southeast Europe, and 'behind' the Iron Curtain more generally, and therefore need to be understood in the politico-historical context (cf. De Soto and Dudwick 2000; Hann 2006).

It was only in the wake of the violent dissolution of Yugoslavia and the disintegration of the state socialist regimes throughout Southeast European societies that the region has attracted the attention of more anthropologists from the centres. At the same time, there has been active research carried out by social historians and political scientists, local as well as foreign folklorists, and ethnologists concentrated around 'alternative centres' and languages (German) mainly associated with the University of Graz; however, their impact on, or fostering of a dialog with the 'centres' of anthropological knowledge production have been arguably limited. What is emerging now in front of our eyes is a story of how a place (e.g. the former Yugoslavia, the Balkans, Southeast Europe) can become an object of analysis overnight. However, different trajectories of political disintegrations and their aftermaths in the region have embraced its parts with different theoretical wholes. For example, the former Yugoslavia has for the most part been studied as a post-conflict place, thereby cut off from the so-called postsocialist scholarship (e.g. Gilbert 2006) that, on the contrary, flourished in other parts of the very same region (e.g. Verdery 2003; Kaneff 2004). Using Appadurai's toolbox, we can observe which places and what themes and concepts have become gatekeeping ones, only to discover a predominance of debates on ethno-religious identity and interactions, tolerance-antagonism dynamism, nationalism, post-conflict reconciliation, symbolic geography of the Balkans, or transformation of property relations. In such a diversity of debates and emergent objects of anthropological knowledge in the centres, we want to move in this issue to the margin of the scholarships to explore and assess 
the meanings, experiences and actions vernacular Islam plays in divergent contexts of social life in Southeast Europe.

In order to break away from the dominant scholarship and to recast new directions of anthropological research on Islam in the region, we feel that it is necessary to carve a space for such an enterprise. The development of the scholarship in the anthropological centres on Southeast European Muslim communities followed the aforementioned logic of attention, and accentuated only certain topics and perspectives while excluding others. The same can also be argued about the anthropology of Islam practiced in the centres (Eickelman and Piscatory 1996; Marranci 2008), and its disinterest in the margins of the Muslim world such as the Balkans, considering a low number of books and academic papers available in academic databases on the subject. Furthermore, there is a problem with the ways academic knowledge from/of/in the region, in regard to vernacular Islam, circulates within the wider anthropological community. This situation could be described, following Michał Buchowski's argument, as an 'attitude and ignorance toward locally produced knowledge [that] still persists with regard to various European regions' (2012: 26). As each contribution in this issue illustrates, there is a rich and vibrant local ethnographic research tradition on Muslims' everyday life that is worth, and indeed essential to be in dialogue with to get rid of the hierarchies in the knowledge production of vernacular Islam in Southeast Europe.

Finally, we argue that any research enterprise on vernacular Islam will have to, in one way or another, reflect on and critically engage with these knowledge hierarchies. Here we conceive of the hierarchy chiefly as the key trope to understand academic production and practice in/about the region. Indeed, a critical scholarship of how the knowledge economy is fabricated and the flows of knowledge channelled enables us to move from the centres of attention to the margins where Southeast European vernacular Islam dwells and is 'written on the body, inscribed on built space and landscapes, or where it is present in a silenced or silent mode' (Pina-Cabral and Pine 2008: 4). This collection, however, does not aspire, misleadingly, to replace one set of knowledge hierarchies with another one (cf. Fabian 2012: 63). Contrarily, in exploring vernacular Islam in Southeast Europe, we call for a reflexive and more nuanced scholarship, that will be politically sensitive, historically informed and ethnographically embedded as the essays in this issue demonstrate. 
David Henig is a lecturer in social anthropology at the School of Anthropology and Conservation, University of Kent. He has carried out ethnographic research in Bosnia-Herzegovina, Kosovo, Dagestan and Tajikistan, focusing on vernacular Muslim cosmologies and dervish orders, socialist/post-socialist social and economic transformations, and exchange and materiality. He has co-authored several papers in American Ethnologist, Anthropology Today, Critique of Anthropology, History and Anthropology, and is currently co-editing the book Economies of Favours after Socialism (to be published in 2014, OUP).

Karolina Bielenin-Lenczowska is Assistant Professor at the Institute of Ethnology and Cultural Anthropology, University of Warsaw. A social anthropologist and linguist, she has conducted ethnographic fieldwork in the Republic of Macedonia since 2001. She is an editor of the book Neighbourly Ties in the Face of Conflict: Social and Ethnic Relations in Western Macedonia (in Polish, Warsaw 2009) and has published on Islam, migration, gender and methodology inter alia in Anthropological Notebooks, Ethnologia Balkanica and Ethnologia Polona.

\section{Acknowledgements}

We would like to thank to Glenn Bowman, Matt Hodges, Anna Kijewska, Emma O'Driscoll, Joao de Pina-Cabral, and Eleanor Ryan-Saha for their invaluable help during different stages. We are also grateful to Ullrich Kockel, the editor of $A J E C$, for his patience. All responsibility for any mistakes rests solely with the authors. This publication was supported by the Ministry of Science and Higher Education in Poland (grant no. N N109 094839). 


\section{References}

Appadurai, A. (1986), 'Theory in Anthropology: Center and Periphery', Comparative Studies in Society and History 28, no. 2: 356-361.

Bougarel, X., E. Helms and G. Duijzings (2007), 'Introduction', in X. Bougarel, E. Helms, and G. Duijzings (eds), The Nerw Bosnian Mosaic: Identities, Memories and Moral Claims in a Post-war Society (Aldershot: Ashgate), 1-35.

Bringa, T. (1995), Being Muslim the Bosnian Way: Identity and Community in a Central Bosnian Village (Princeton: Princeton University Press).

Buchowski, M. (2006), 'The Specter of Orientalism in Europe: From Exotic Other to Stigmatized Brother', Anthropological Quarterly 79, no. 3: 463-482.

Buchowski, M. (2012), 'Intricate Relations between Western Anthropologists and Eastern Ethnologists', Focaal: Journal of Global and Historical Anthropology 63: 2038.

Creed, G. W. (2011), Masquerade and Postsocialism: Ritual and Cultural Dispossession in Bulgaria (Bloomington: Indiana University Press).

De Soto, H. G. and N. Dudwick (eds) (2000), Fieldwork Dilemmas: Anthropologists in Postsocialist States (Madison: University of Wisconsin Press).

Duijzings, G. (2000), Religion and the Politics of Identity in Kosovo (London: Hurst).

Edgar, I. and D. Henig (2010), 'Istikhara: The Guidance and Practice of Islamic Dream Incubation', History and Anthropology 21, no. 3: 251-262.

Eickelman, D. and J. Piscatory (1996), Muslim Politics (Princeton: Princeton University Press).

Fabian, J. (1983), Time and the Other: How Anthropology Makes Its Objects (New York: Columbia University Press).

Fabian, J. (2012), 'Comments on "Changing Global Flows in Anthropological Knowledge", Focaal - Journal of Global and Historical Anthropology 63: 62-65.

Ghodsee, K. (2010), Muslim Lives in Eastern Europe: Gender, Ethnicity, and the Transformation of Islam in Postsocialist Bulgaria (Princeton: Princeton University Press).

Gilbert, A. (2006), 'The Past in Parenthesis: (Non)post-Socialism in Post-war BosniaHerzegovina', Anthropology Today 22, no. 4: 14-18.

Green, S. (2005), Notes From the Balkans: Locating Marginality and Ambiguity on the GreekAlbanian Border (Princeton: Princeton University Press).

Halpern, J. M. and D. A. Kideckel (1983), 'Anthropology of Eastern Europe', Annual Review of Anthropology 12: 377-402.

Hann, C. (ed.) (2006), The Postsocialist Religious Question: Faith and Power in Central Asia and East-Central Europe (Berlin: LIT).

Henig, D. (2012), “This Is Our Little Hajj”: Muslim Holy Sites and Reappropriation of the Sacred Landscape in Contemporary Bosnia', American Ethnologist 39, no. 4: $752-766$.

Jasarević, L. (2012), 'Pouring out Postsocialist Fears: Practical Metaphysics of a Therapy at a Distance', Comparative Studies in Society and History 54, no. 4: 914-941.

Kaneff, D. (2004), Who Owns the Past? The Politics of Time in a "Model" Bulgarian Village (Oxford: Berghahn).

Marranci, G. (2008), The Anthropology of Islam (Oxford: Berg). 
Pina-Cabral, J. de and F. Pine (2008), 'On the Margins: An Introduction', in F. Pine and J. de Pina-Cabral (eds), On the Margins of Religion (Oxford: Berghahn), $1-10$.

Schendel, W. v. (2002), 'Geographies of Knowing, Geographies of Ignorance: Jumping Scale in Southeast Asia', Environment and Planning D: Society and Space 20: 647668.

Sorabji, C. (1989), 'Muslim Identity and Islamic Faith in Sarajevo', Ph.D. diss. (University of Cambridge).

Verdery, K. (2003), The Vanishing Hectare: Property and Value in Postsocialist Transylvania (Ithaca: Cornell University Press). 